Sains Malaysiana 50(4)(2021): 907-918

http://doi.org/10.17576/jsm-2021-5004-03

\title{
Seasonal Dynamics of Stomach Contents, Trophic Level, Length-Weight Relationship and Condition Factor of Mystus bleekeri (Day, 1877)
}

(Dinamik Bermusim daripada Kandungan Perut, Aras Trofik, Hubungan Panjang-Berat dan Faktor Keadaan daripada Mystus bleekeri (Day, 1877))

\author{
Sabuj Kanti Mazumder, Mrityunjoy Kunda, Mohammed Mahbub Iqbal, Lipi Rani BasaK \& Simon \\ KUMAR DAS*
}

\begin{abstract}
The Asian catfish Mystus bleekeri is a popular food fish along with favored as an ornamental fish in Bangladesh. Till now detailed report on stomach contents, trophic level, length-weight relationship and condition factor of this fish species in the agro-climatic context of Bangladesh is lacking. Hence, the aims of this study were to describe the stomach content, trophic level, length-weight relationship (LWR) and condition factors of Mystus bleekeri collected from Dekhar Haor, Sylhet, Bangladesh from July 2017 to June 2018. A total of 600 specimens ranging from 6.9-24.6 cm total length (TL) and 5.7-72.4 g body weight (BW) was analyzed in this study. Stomach content analysis showed that the fish fed mostly on Mollusca with a frequency of occurrence $\left(f_{0}: 25.36 \%\right)$ and worms $\left(f_{0}: 21.68 \%\right)$, followed by plant matters $\left(f_{0}\right.$ : $3.32 \%)$, Cladocerana $\left(f_{:}: 1.18 \%\right)$, Copepoda $\left(f_{0}: 0.95 \%\right)$, and Teleostei $\left(f_{0}: 0.36 \%\right)$. The estimated mean trophic level (TROPH) ranged from $2.35 \pm 0.13$ in December to $3.02 \pm 0.23$ in August, indicating that they are opportunistic feeder. The LWR analysis showed negative allometric growth $(b<3)$ throughout the year. The values of the exponent $b$ in the $L W R\left(W=a L^{b}\right)$ vary between 1.474 and 2.490. The mean $K$ value was significantly higher in October indicating the heavier weight and better condition of the fish $(P<0.05)$. The data obtained from this study would be useful to introduce sustainable management of Mystus bleekeri not only in Dekhar Haor but also in other inland waters of Bangladesh.
\end{abstract}

Keywords: Condition factor; length-weight relationship; Mystus bleekeri; stomach content; trophic level

\section{ABSTRAK}

Ikan keli Asia Mystus bleekeri merupakan sajian ikan yang popular dan digemari sebagai ikan hiasan di Bangladesh. Sehingga kini laporan terperinci terhadap kandungan perut, aras trofik, hubungan panjang-berat dan faktor keadaan daripada spesies ikan ini dalam konteks iklim tani dari Bangladesh adalah kurang. Oleh itu, tujuan kajian ini adalah untuk memperinci kandungan perut, aras trofik, hubungan panjang-berat (LWR) dan faktor keadaan Mystus bleekeri yang dikumpul dari Dekhar Haor, Sylhet, Bangladesh dari Julai 2017 sehingga Jun 2018. Sejumlah 600 spesimen berjulat antara 6.9-24.6 cm daripada jumlah panjang (TL) dan 5.7-72.4 g daripada berat badan (BW) telah dicirikan dalam kajian ini. Analisis kandungan perut mendedahkan bahawa ikan yang diberi makan paling banyak Mollusca dengan kekerapan frekuensi $\left(f_{o}: 25.36 \%\right)$ dan cacing $\left(f_{o}: 21.68 \%\right)$, diikuti oleh jenis tumbuhan $\left(f_{\circ}: 3.32 \%\right)$, Cladocerana $\left(f_{o}\right.$ : $1.18 \%)$, Copepoda $\left(f_{0}: 0.95 \%\right)$ dan Teleostei $\left(f_{0}: 0.36 \%\right)$. Purata aras trofik (TROPH) telah dianggarkan berjulat dari $2.35 \pm 0.13$ dalam Disember ke 3.02 \pm 0.23 dalam Ogos, menunjukkan bahawa mereka merupakan pemakan oportunis. Analisis LWR menunjukkan terdapat pertumbuhan alometrik negatif $(b<3)$ sepanjang tahun. Nilai eksponen b dalam LWR $\left(W=a L^{b}\right)$ berjulat antara 1.474 ke 2.490. Purata nilai K adalah ketara lebih tinggi pada bulan Oktober menunjukkan berat yang lebih tinggi dan keadaan yang lebih paik pada ikan $(P<0.05)$. Data yang diperoleh daripada kajian ini dapat digunakan untuk memperkenal pengurusan secara lestari untuk Mystus bleekeri bukan sahaja di Dekhtar, Haor tetapi di kawasan pedalaman berair di Bangladesh.

Kata kunci: Aras trofik; faktor keadaan; hubungan panjang-berat; kandungan perut; Mystus bleekeri 


\section{INTRODUCTION}

Haor is a wetland ecosystem of great importance in Bangladesh for meeting local and regional demand for fish production, maintaining biodiversity, and also serve as a good source of fish seed supply for adjacent water bodies (Pandit et al. 2015). Dekhar Haor is one of the most important Haors in Bangladesh. It is made up of 36 small, medium and large interconnecting beels, canals, rivers, and crop lands (CNRS 2004). It is the home for many species of freshwater fishes and thousands of indigenous birds. The Haor is also a harbor of non-fish organisms like snails, mussels and different types of aquatic vegetation. However, Dekhar Haor is gradually silted up due to flash floods and other manmade causes. Overfishing is also a common practice in this area. In these circumstances, research work is very important to comprehend the core problems of it, biology of the species available in this water body and thereby keep the proper management steps (Pandit et al. 2015).

The Asian catfish Mystus bleekeri (Day 1877) is a small, freshwater catfish belongs to the order Siluriformes and family Bagridae. This species usually inhabits in streams, rivers, side channels, reservoirs, marginal vegetation in lakes, swamps and coastal beds with muddy substrates. Despite its small size, it is a favourable food fish, having good taste and nutritional value in terms of protein, micronutrients, vitamins and minerals (Tiwana et al. 2007). Due to these reasons, it has an increasing demand in both domestic and export markets (Hossain et al. 2006). The food and feeding habitats of fish are crucial characteristic of the life-history strategy of a species to know the foremost necessary functional role of the fish inside their living ecosystems (Abdel-Aziz \& Gharib 2007). Gut content analysis data are useful to understand the predator-prey relationship and identify the food preferences of a fish species. Such information can be used to assess conservative regulations and policies (Bandpei et al. 2012; Lopez-Peralta \& Arcila 2002; Mazlum \& Akgumus 2019).

Additionally, the key role of feeding studies for biology, ecology, and more importantly for fisheries management, was uncovered only the last decade with the use of trophic level (TROPH) in predicting the fishing for the balance of aquatic food webs. The trophic level, which for aquatic animals' ranges between 2 (for herbivores/ detritivores) and 5.5 (specialized predators of marine mammals), expresses the relative position of an animal in the food webs that nourish them (Pauly et al. 2000).

Quantitative aspects of fish such as length-weight relationship (LWR), condition factor, sex ratio, growth, recruitment, and mortality are important tools for studying fish biology. Length and weight measurements can give information on the stock composition, life span, mortality, growth and production. Data on LWR also provide important clues on climate and environmental changes and change in human subsistence (Kumar et al. 2014).

The condition factors (Fulton condition factor $K$ and relative condition factor $K n$ ) are commonly used to analyses the wellbeing of fishes in natural environment (Daliri et al. 2014). A fish that is heavier for a given length (higher condition index) is generally considered to be healthier because extra weight means extra energy reserves. Lighter fish lack energy reserves and tend to be more susceptible to environmental stressors. Published information on stomach contents, trophic level, LWRs and condition factors of $M$. bleekeri in the wetland ecosystem context (e.g. Haors) of Bangladesh is scarce (Musa \& Bhuiyan 2007; Roy \& Hossain 2006). Therefore, the aims of this study were to measure seasonality in stomach contents, trophic level, LWR, and condition factors of $M$. bleekeri collected from Dekhar Haor waters of Bangladesh. This information will enhance management, conservation and culture of this species and also allow for future comparisons between the populations of same species.

\section{MATERIALS AND METHODS}

\section{SAMPLE COLLECTION}

The $M$. bleekeri samples were collected monthly interval from July 2017 to June 2018 from Dekhar Haor (2434' N to $25^{\circ} 12^{\prime} \mathrm{N}$ and $90^{\circ} 56^{\prime} \mathrm{E}$ to $91^{\circ} 49^{\prime} \mathrm{E}$ ), Sylhet, the northeast part of Bangladesh (Figure 1). A total of 600 fish samples were collected using traditional fishing gears including three-layered trammel net, cast net, scoop net, and trap. The mesh sizes (stretched length) of the trammel nets (three layered) were $4.2,6.5$, and $7.5 \mathrm{~cm}$, and casts nets were $2 \mathrm{~cm}$. After hauling, the catch was removed, washed well, and confirmed to the species level according to Lagler (1966). Formaldehyde 4\% (w/v) was injected into the fish samples right after hauled and chilled in an ice chest to prevent further digestion of the stomach contents during transit from the sampling sites to the laboratory (Mazumder et al. 2019, 2018).

\section{MORPHOMETRIC MEASUREMENTS}

Total length (L) of fish samples were measured from the tip of the snout (mouth closed) to the extended tip of the caudal fin. The lengths were taken with fish measuring board (MariSource, Canada) to the nearest $0.1 \mathrm{~cm}$. Body weight (W) was measured to the nearest $0.1 \mathrm{~g}$ with an electric balance (Model: KD-300KC, Fujian, China) after removing the adhered water and other particles from the surface of body (Mazumder et al. 2016). 


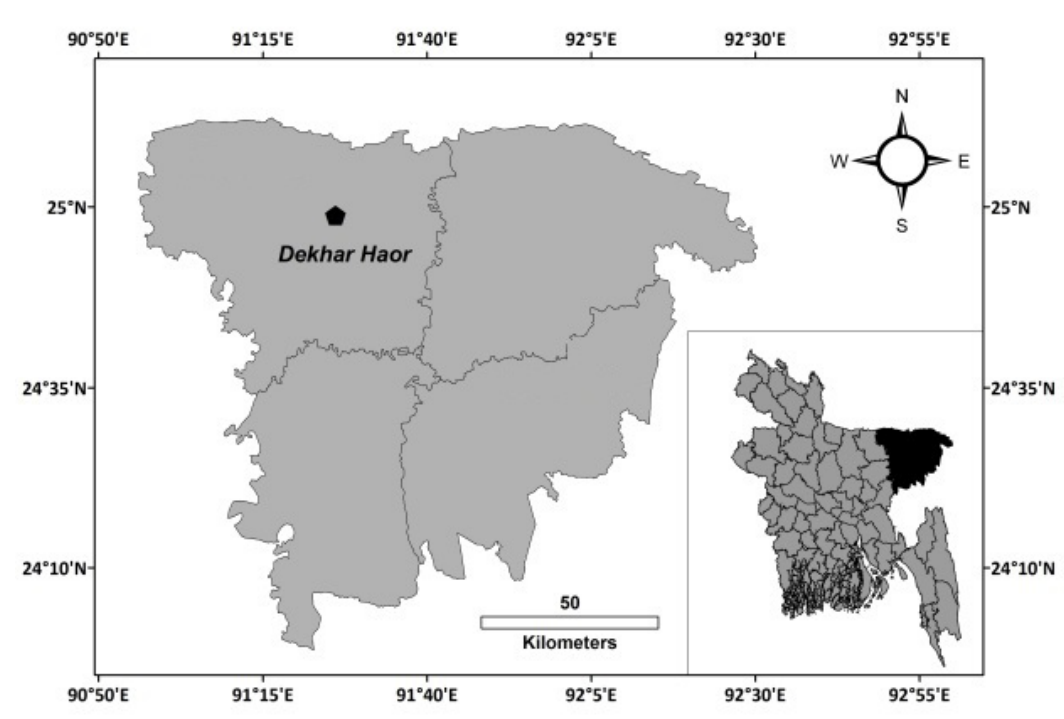

FIGURE 1. Map of Bangladesh showing the study site ( ) from where the samples of $M$. bleekeri were collected

\section{STOMACH CONTENT ANALYSIS}

Each intact stomach was slit open using a pair of fine scissors and emptied on a Petri dish for measurements with the help of zoom dissection phase contrast microscope (Model: BM1350B, New Jersey, USA). The stomach distension was categorized as: quarter filled ( $<25 \%$ filled); half filled (25-50\% filled); three quarter filled (50-75\% filled); and full filled (75-100\% filled), as modified from Chitravadivelu and Sivapalan (1984). The sub-samples were then quantified adopting frequency of occurrence $\left(f_{\mathrm{o}}\right)$ by Bagenal and Tesch (1978) and numerical methods by Hyslop (1980).

\section{TROPHIC LEVEL ANALYSIS}

The trophic level of individual fish was estimated using (1) (Pauly et al. 2000):

$$
\mathrm{TROPH}_{i}=1+\sum_{j=1}^{G}\left(D C_{i j} \times T_{R O P H_{J}}\right)
$$

where TROPHj is the fractional trophic level of prey $\mathrm{j}$; DCij represents the fraction of $\mathrm{j}$ in the diet of an individual fish I; and $G$ is the total number of prey species in a stomach.

Thus defined, the trophic level ranges between 2.0 for herbivorous/detrivorous and 5.0 for piscivorous/ carnivorous species (Pauly et al. 2000). The mean values $( \pm$ S.E.) estimated from the equation were input into the Microcal Origin v 8.0 graphic software (OriginLab,
Northampton, MA) (Simon \& Mazlan 2010; Simon et al. 2009) for acquiring the trophic position pattern according to the fish size class.

\section{LENGTH WEIGHT RELATIONSHIP}

The relationship between TL and BW was fitted to data, for each month, with a nonlinear regression (2) (Froese 2006):

$$
B W=\mathrm{a} T L^{\mathrm{b}},
$$

where $B W$ is the body weight in $\mathrm{g}$; and $T L$ is the total length in $\mathrm{cm}$. The coefficient $a$ is the intercept of the regression, and the regression coefficient $b$ is an exponent expressing the relationship between length and weight. When $b$ is equal to three (3), isometric pattern of growth occurs but when $b$ is not equal to 3 , allometric pattern of growth occurs, which may be positive if $>3$ or negative if $<3$ (De et al. 2016).

\section{CONDITION FACTORS}

To compare the conditions of fish populations throughout the year Fulton, $K=100 B W / T L^{3}$, (Fulton 1904) and relative condition factor equation (3) (Le Cren 1951), were calculated:

$$
K \mathrm{n}=B W\left(\mathrm{a} T L^{\mathrm{b}}\right)^{-1(3)}
$$

where $B W$ is the individual fish weight; $T L$ is the individual fish total length; $a$ is the intercept; $b$ is the slope; and 100 is a factor to bring the value of $K$ near unity. The 
value of $a$ and $b$ from the length-weight relationship were employed in calculating the Kn (Mazumder et al. 2016; Simon et al. 2013).

\section{STATISTICAL ANALYSIS}

Prior to the statistical analysis, all data were tested for normality and homogeneity of variance among the different groups using a Kolmogornov-Smirnov (K-S) test and Bartlett's test for homogeneity of variance (Sokal \& Rohlf 1995). Preliminary statistics (mean and standard deviation) were computed seasonally for TROPH, $B W, T L$, $K$ and $K \mathrm{n}$. Determination of $a$ and $b$ values was performed using a non-linear regression of which the curve fitting was carried out by Chi-square $\left(\chi^{2}\right)$ iterative methods using Levenberg-Marquardt and Simplex algorithms readily developed in Microcalc Origin ${ }^{\mathrm{TM}}$ v 8.0 computer software (Das et al. 2014). The measurement of model fit (goodness of fit of calculated $T L$ and $B W$ ) was evaluated by the coefficient of determination $\left(r^{2}\right)$. One-way analysis of variance $(\mathrm{P}=0.05)$ was carried out to test the effect of monthly variation of TROPH and condition factors $(K, K \mathrm{n})$. Values in the text are expressed as mean \pm S.E. All statistical analyses were performed using MINITAB (version 14), and Microcalc Origin ${ }^{\mathrm{TM}}$ v 8.0 software.

\section{RESULTS}

\section{STOMACH CONTENT ANALYSIS}

A total of $600 \mathrm{M}$. bleekeri (size range $6.9-24.6 \mathrm{~cm}$ TL) stomachs were examined and none of them were with empty gut content. Out of $600 \mathrm{M}$. bleekeri's stomachs 72 stomachs $(12 \%)$ were quarter filled $(<25 \%$ filled), 240 stomachs $(40 \%)$ were half filled $(25-50 \%$ filled), and 162 stomachs $(27 \%)$ were three quarter filled $(50-75 \%$ filled) whereas, 132 stomachs (22\%) were full filled (75$100 \%$ filled).

A total of eight major groups of prey items which includes mollusc, worm, insect, plant, copepod, teleost, detritus, and debris were made up of the stomach contents (based on their presence and digestion status in the stomachs) of M. bleekeri (Table 1). Mollusks mostly consist of Pila globosa juvenile and glochidium larvae with the $f_{0} 25.36 \%$. Worms (earth worm) were observed with the average frequency of occurrence $\left(f_{\mathrm{o}}\right) 21.68 \%$. Insects comprises with coleoptera and plecoptera larvae accounted for $f_{\mathrm{o}} 11.61 \%$ followed by plant matters (e.g. herbs, grasses or small leaves) and cladocerans, forming a diet with a $f_{\mathrm{o}} 3.32 \%$ and $1.18 \%$ respectively. Copepods and teleosts (small size of fish likely P. ticto and their body parts) were reported with a $f_{0} 0.95 \%$ and $0.36 \%$ of the diet, respectively. Other prey items included organic detritus and debris which were found in all the guts.

TABLE 1 . Monthly percentage frequency of different prey types in the gastro-intestine of M. bleekeri from July 2017 to

June 2018

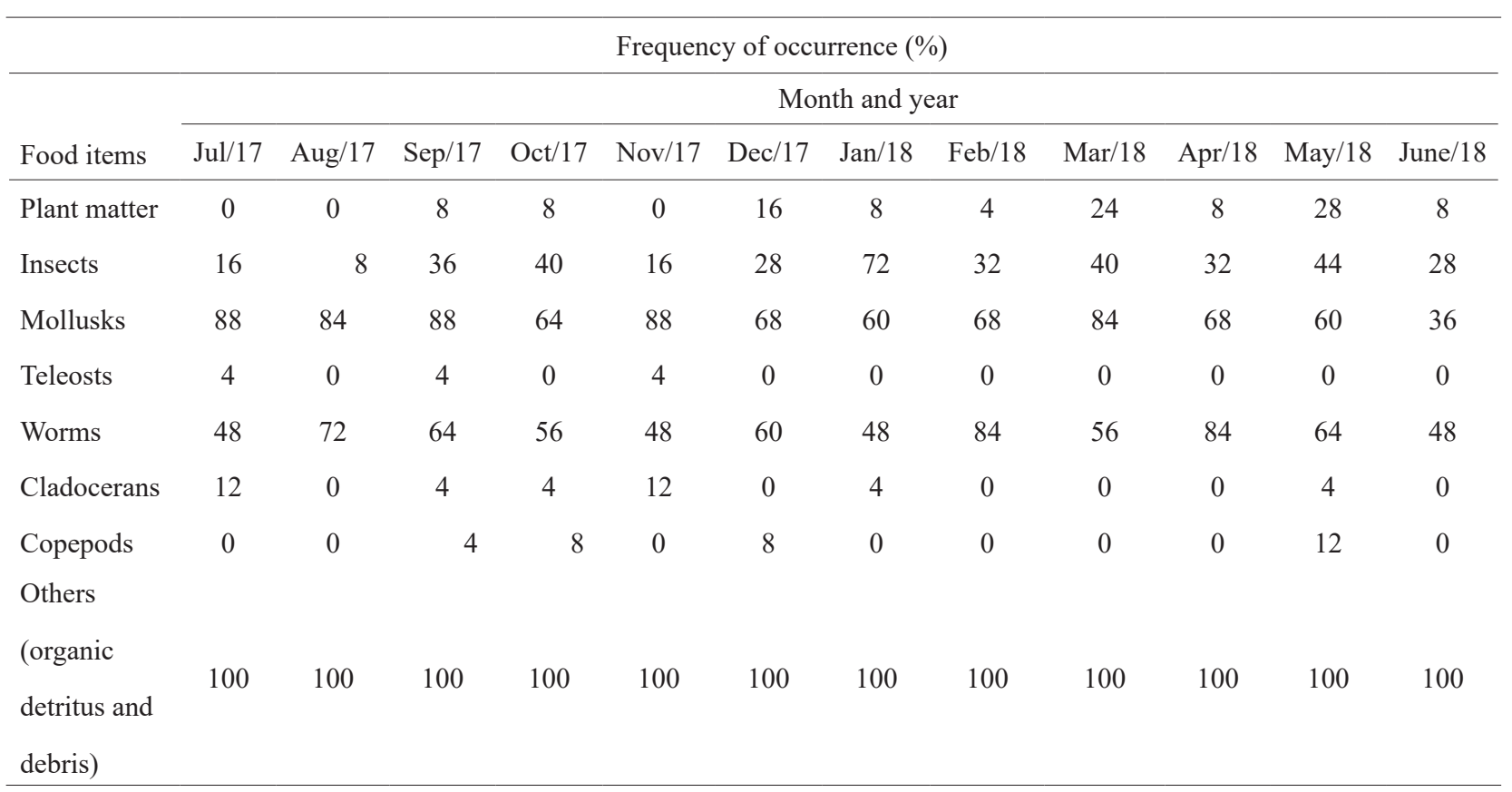

The estimated trophic level (TROPH) ranged from $2.41 \pm 0.06$ in December to 3.02 \pm 0.07 in June with mean value of $2.73 \pm 0.06$ (Figure 2) indicating M. bleekeri are opportunistic feeder/omnivorous in nature. One-way ANOVA analysis showed that, the mean TROPH in June $(3.02 \pm 0.07)$ was significantly higher $(P<0.05)$ than that 
of the values from July $(2.59 \pm 0.05)$ to December $(2.41$ \pm 0.06 ). Conversely, the mean TROPH value in December

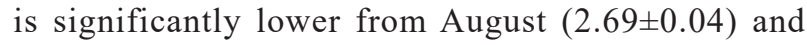

October $(2.76 \pm 0.06) 2017$, and from January to June $2018(\mathrm{~F}=11.38, P<0.001)$. Other mean TROPHs are not significantly differed from each month $(P>0.05)$ (Figure 2).

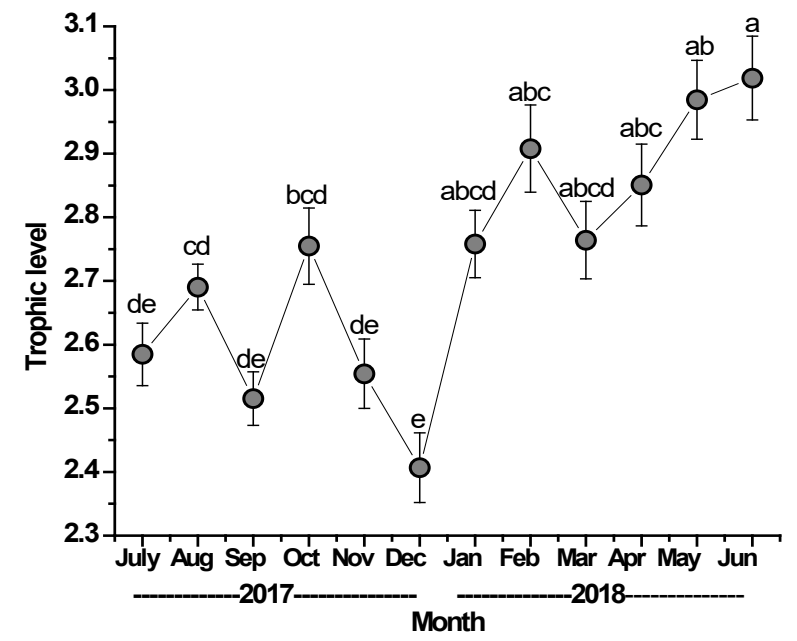

FIGURE 2. Monthly mean TROPH of M. bleekeri collected from Dekhar Haor, Bangladesh from July 2017 to June 2018. Solid circles represent mean trophic level whereas bars represent variants of prey items

However, there was a clear trend between trophic level and $T L$ of $M$. bleekeri. The trophic level was increased with fish size indicating ontogenetic diet shifting in $M$. bleekeri yet the rate is different in different month (Figure 3(a) - 3(1)). For example, in July and December
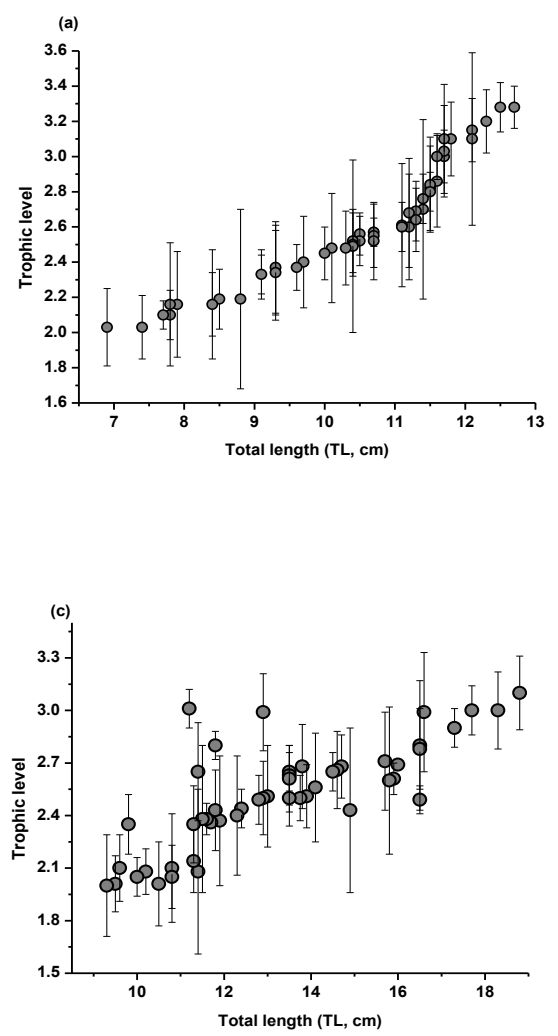

2017, the increasing trend was nonlinear whereas, in September, October 2017 and February, April, May and June 2018 the pattern was somewhat linear. On the other hand, in August the data are scatteredly distributed and others are somewhat sigmoidal pattern.
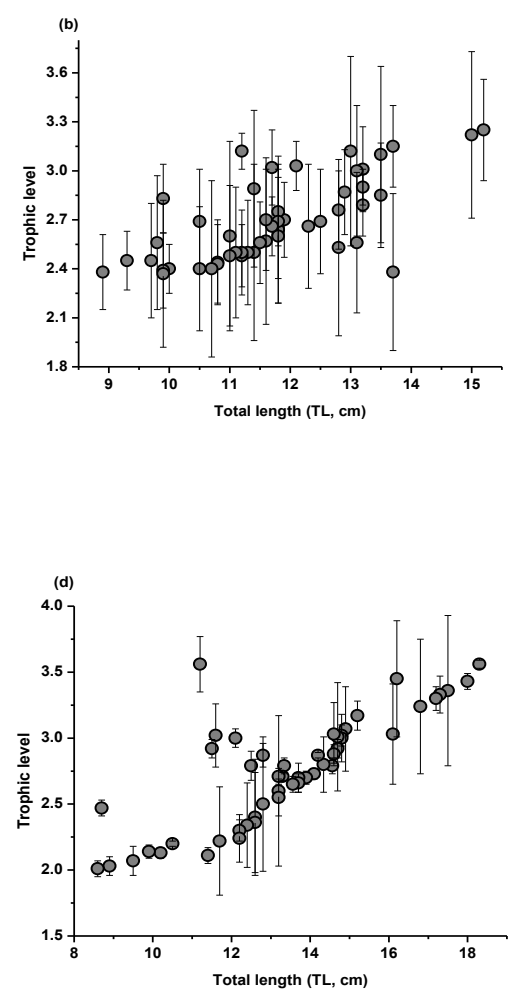

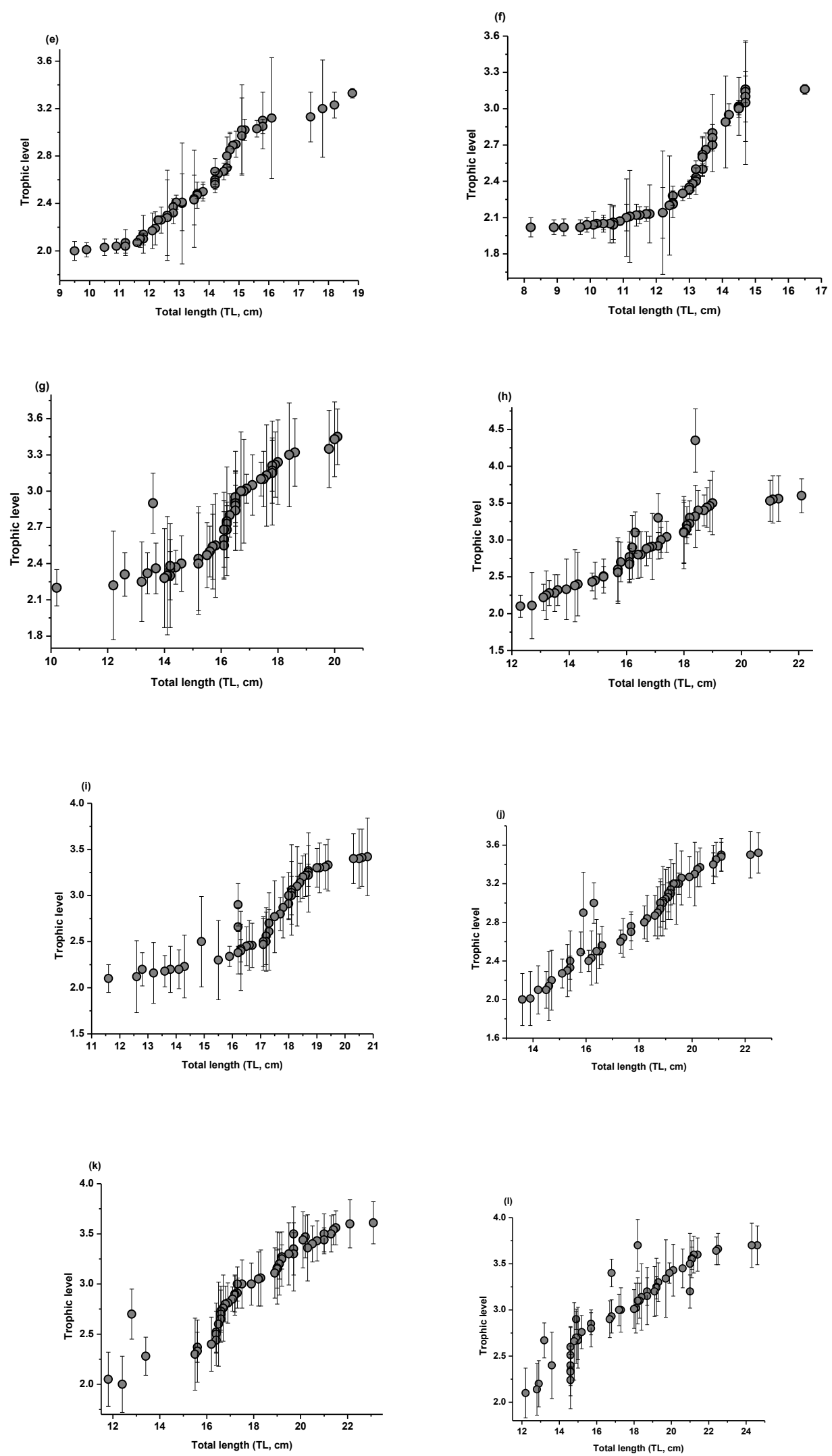

FIGURE 3. Trophic level-size relationship of M. bleekeri collected from Dekhar Haor, Bangladesh from July 2017 to June 2018 (a) July, (b) August, (c) September, (d) October, (e) November, (f) December, (g) January, (h) February, (i) March, (j) April, (k) May, and (l) June. Solid circles represent mean trophic level and bars represent variants of prey items. The pooled standard error was used to calculate the intervals 
LENGTH-WEIGHT RELATIONSHIP ANALYSIS

Results obtained from the LWRs from $300 \mathrm{M}$. bleekeri fish at different months are given in Table 2. In terms of growth type, the $M$. bleekeri showed a negative allometric growth $(b<3)$ in all the months, indicating that the fish became lighter with increasing size. The exponent $b$ ranged from $1.474 \pm 0.152$ in July to $2.490 \pm 0.173$ in October, meaning that all slopes $(b)$ were within the expected ranges $(2.0<b<4.0)$ (Bagenal \& Tesch 1978) except in July. The correlation coefficient values in different months of $M$. bleekeri ( $r^{2}$ ranged from $0.569-0.906$ ) showed that the observed and calculated length and weight relationships were closely fitted. The highly correlation observed in the month of September, November, December, and March to June ( $r^{2}$ ranged from $\left.0.820-0.906\right)$.

TABLE 2. Monthly regression coefficients of length-weight relationships of M. bleekeri in the Dekhar Haor, Bangladesh from July 2017 to June 2018

\begin{tabular}{lcccccccc}
\hline Month and year & $\mathrm{a} \pm \mathrm{S} . \mathrm{E}$ & $b \pm \mathrm{S} . \mathrm{E}$ & $r^{2}$ & $\chi^{2}$ & Equation & $\mathrm{GT}$ & $K$ & $K \mathrm{n}$ \\
\hline July/17 & $0.302 \pm 0.110$ & $1.474 \pm 0.152$ & 0.692 & 1.652 & $\mathrm{~W}=0.302 \mathrm{~L}^{1.474}$ & $\mathrm{~A}-$ & $0.8546 \pm 0.275^{\mathrm{B}}$ & $1.006 \pm 0.106^{\mathrm{G}}$ \\
August/17 & $0.040 \pm 0.088$ & $2.323 \pm 0.184$ & 0.761 & 3.645 & $\mathrm{~W}=0.040 \mathrm{~L}^{2.32}$ & $\mathrm{~A}-$ & $0.706 \pm 0.099^{\mathrm{B}}$ & $0.989 \pm 0.132$ \\
September/17 & $0.101 \pm 0.027$ & $2.018 \pm 0.098$ & 0.906 & 5.707 & $\mathrm{~W}=0.101 \mathrm{~L}^{2.018}$ & $\mathrm{~A}-$ & $0.768 \pm 0.093^{\mathrm{B}}$ & $1.028 \pm 0.070^{\mathrm{G}}$ \\
October/17 & $0.067 \pm 0.042$ & $2.140 \pm 0.231$ & 0.656 & 21.931 & $\mathrm{~W}=0.067 \mathrm{~L}^{2.140}$ & $\mathrm{~A}-$ & $0.743 \pm 0.200^{\mathrm{B}}$ & $1.216 \pm 0.306^{\mathrm{G}}$ \\
November/17 & $0.129 \pm 0.036$ & $1.928 \pm 0.105$ & 0.875 & 5.005 & $\mathrm{~W}=0.129 \mathrm{~L}^{1.928}$ & $\mathrm{~A}-$ & $0.780 \pm 122^{\mathrm{B}}$ & $0.989 \pm 110$ \\
December/17 & $0.077 \pm 0.030$ & $2.089 \pm 0.149$ & 0.820 & 4.155 & $\mathrm{~W}=0.077 \mathrm{~L}^{2.089}$ & $\mathrm{~A}-$ & $0.746 \pm 139^{\mathrm{B}}$ & $1.030 \pm 141^{\mathrm{G}}$ \\
January/18 & $0.387 \pm 0.232$ & $1.605 \pm 0.214$ & 0.569 & 33.879 & $\mathrm{~W}=0.387 \mathrm{~L}^{1.605}$ & A- & $0.882 \pm 0.180^{\mathrm{B}}$ & $1.000 \pm 0.149^{\mathrm{G}}$ \\
February/18 & $0.339 \pm 0.172$ & $1.674 \pm 0.172$ & 0.652 & 40.074 & $\mathrm{~W}=0.339 \mathrm{~L}^{1.674}$ & A- & $0.859 \pm 0.243^{\mathrm{B}}$ & $1.009 \pm 0.182^{\mathrm{G}}$ \\
March/18 & $0.212 \pm 0.073$ & $1.795 \pm 0.120$ & 0.847 & 10.152 & $\mathrm{~W}=0.212 \mathrm{~L}^{1.795}$ & $A-$ & $0.733 \pm 0.117^{\mathrm{B}}$ & $1.002 \pm 0.078^{\mathrm{G}}$ \\
April/18 & $0.140 \pm 0.051$ & $2.01 \pm 0.121$ & 0.868 & 23.523 & $\mathrm{~W}=0.140 \mathrm{~L}^{2.010}$ & A- & $0.856 \pm 0.135^{\mathrm{B}}$ & $1.002 \pm 0.117^{\mathrm{G}}$ \\
May/18 & $0.39 \pm 0.015$ & $2.490 \pm 0.173$ & 0.835 & 35.499 & $\mathrm{~W}=0.39 \mathrm{~L}^{2.490}$ & A- & $0.704 \pm 0.147^{\mathrm{B}}$ & $1.024 \pm 0.193^{\mathrm{G}}$ \\
June/18 & $0.07 \pm 0.024$ & $2.14 \pm 0.103$ & 0.900 & 21.238 & $\mathrm{~W}=0.07 \mathrm{~L}^{2.14}$ & A- & $0.677 \pm 0.109^{\mathrm{B}}$ & $1.03 \pm 0.122^{\mathrm{G}}$ \\
\hline
\end{tabular}

${ }^{\dagger} \mathrm{a}=$ Intercept, $\mathrm{b}=$ Regression coefficient, data are express as mean \pm standard error (SE), $\mathrm{n}=50 . \mathrm{GT}=$ Type of growth, $-\mathrm{A}$ : negative allometric growth; G: good condition; B: poor condition

\section{CONDITION FACTORS}

The mean $K$ and $K$ n for $M$. bleekeri ranged from 0.695 \pm 0.022 in June 2018 to $0.906 \pm 0.042$ in July 2018, and $0.934 \pm 0.023$ in January 2018 to $1.241 \pm 0.052$ in October 2017, respectively. The mean monthly $K$ decline impulsively from July $(0.906 \pm 0.042)$ to August $(0.756 \pm$ 0.021 ) and followed a zigzag pattern up to February 2018 and again sharply declined in March $(0.713 \pm 0.026)$. From March the mean monthly values again increased steadily and then slop down to June to reach the lowest point $(0.695 \pm 0.022)$. However, the mean $K$ values in July is significantly higher $(P<0.05)$ than the values in August and October 2017, and March, May and June 2018 (df = $11, \mathrm{~F}=5.36, P<0.001)$. Conversely, the mean $K$ value in June $0.695 \pm 0.022$ was significantly lower than the mean $K$ values of July 2017 and January, February, April $2017(P<0.05)$ (Figure 4(a)). Contrariwise, the mean $K n$ followed a similar pattern from July to September 2017 and then sharply increase in October $(1.241 \pm 0.052)$ and again dropped and increased steadily up to January 2018. After that, the values are gradually increase to June 2018 (Figure 4(b)). However, the mean monthly Kn in October was significantly higher than other months except $(\mathrm{df}=$ $11, \mathrm{~F}=3.79, P<0.001)$. 

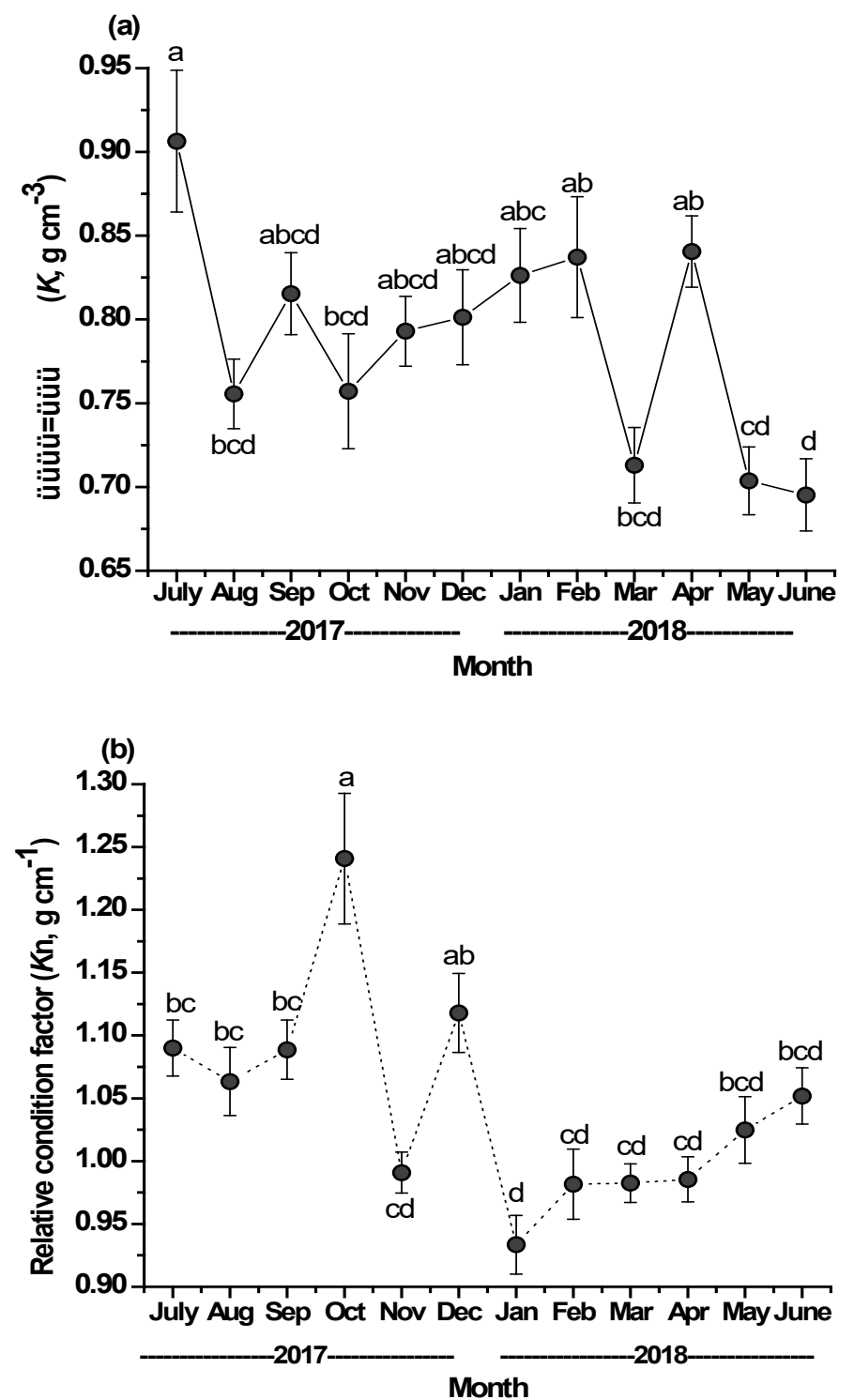

FIGURE 4. Monthly changes in the mean value (solid circle) and range (vertical bars) of (a) Fulton's condition factor $(\mathrm{K})$, and (b) relative condition factor (Kn) of M. bleekeri in the Dekhar Haor, Bangladesh. Means that do not share a letter are significantly different at $\mathrm{P}<0.05$. The pooled standard error was used to calculate the intervals

\section{DISCUSSION}

In the present study, all M. bleekeri stomachs were filled and no empty stomach was encountered. This may reflect short feeding periods and prolonged digestion which is in agreement with Goutham-Bharathi et al. (2013).
The M. bleekeri in Dekhar Haor waters feed primarily on mollusks (mostly Pila globosa juvenile) and worms followed by insects. It is assumed that mollusks were captured from the bottom sediments and also from the vegetation in the studied areas (Layman et al. 2005). The 
method of stomach fullness assessment in the present study allowed to observe the prey items in the stomach by dissection. A similar method of assessment has been also reported by Joyce et al. (2002).

The result obtained from this study is incompatible with the results obtained by Blaber (2000), Das et al. (2014), and Sivakami (1995). However, Sivakami (1995) reported that Megalaspis cordyla in Indian waters also takes other fishes: Silverbellies, Nemipterids, flatfishes, perches; crustaceans: Cladocerans, Squilla spp., alima larvae; molluscs: Morula sp., Nucula sp., Cavolina sp., which were not found in the present study. There is scanty of literature for making a direct comparison with similar fish species. The limited diversity of food items in the diets of the fish studied here may also reflect the short food range of this species.

The estimated TROPH values for $M$. bleekeri are similar to that calculated by Layman et al. (2005) for other species such as Pseudoplaystoma fasciatum, Raphiodon vulpinnis, and Stergiou and Karpouzi (2002) for Gadiculus argenteus and Trachurus trachurus. All these species exhibit similar feeding preference, namely, crustaceans, mollusks, fish larvae, and mysids, and can be considered as largely carnivores. The result from the present study indicate that $M$. bleekeri fish is largely opportunistic predators (with a few exceptions) feeding on a wide spectrum of prey species such as mollusks, worms, crustaceans, insects, and rarely teleost, depending on the food availability in the environment. A negligible quantity of teleosts, copepods, cladocerans, and plant materials indicating their occasional feeding (Blaber 2000). Seasonal variation occurs in the composition of the diet of M. bleekeri fish species because availability of prey items is often cyclic due to factors of their life histories or to climate, or other environmental conditions (Ma et al. 2006).

In the present study, the correlation coefficient " $r$ " value range from 0.681 in January to 0.980 in September. All the fish in all climatic regimes is $<3$. This is an indication that most fishes in Dekhar Haor has negative allometric pattern of growth. This trend has been variously reported in different parts of the world (Onimisi \& Ogbe 2015). Negative allometric growth could be due to variation in water quality parameters, maturing, age, sex, and organ development. Changes in water quality parameters can be influenced by the nature of anthropogenic activities in the Haor and season. For $M$. bleekeri, only one estimate of length-weight and lengthlength relationships was previously available in the global electronic data bank on fishes, 'FishBase' by Hossain and
Afroze (1991), who reported value of the scaling exponent $b$ is 2.666 from Bangladesh. Alam et al. (2018) found the exponent $b$ values from similar habitat in Bangladesh waters are below 2.0, but Hossain et al. (2006) observed the $b$ values were higher than 3.0.

Fulton's $(K)$ condition factor showed apparent growth variation in different seasons. These differences can be attributed to the combination of one or several factors such as the difference in the number of specimens examined and the size range of species (Moutopoulos \& Stergiou 2002). However, during rainy season the fishes showed maximum robustness due to availability of food and suitable environmental condition, which are in confirmatory with the findings of Hoque and Hossain (1992) and Hossain et al. (2006) on Mystus vittatus. The mean relative condition factors $(\mathrm{Kn})$ were greater than 1 in all the seasons except in November. These results show that the fish were physiologically in stable condition (Wade 1992). The variation in mean $K n$ values observed during different months for the species showed only significant difference in October. A low body condition may suggest muscle wasting (proteolysis) indicating a starvation response (Simon et al. 2013). Because of differences in environmental conditions, between systems, different fish populations display different levels of condition according to food availability or catchment characteristics (Boys et al. 2012). The different feeding habits of the fishes, which might have enabled them to obtain food all year round, could have been relevant for their stable physiological condition. Therefore, the seasonal variations did not influence the condition factor of fishes analyzed except in October. This appears to be related to the breeding activities of the fish due to depletion of reserves during post monsoon season. Nonetheless, the climatic conditions and perhaps the water quality dynamic of the water bodies might have played significant roles in shaping the condition factor of the fishes.

\section{CONCLUSION}

The present study has provided a detail report on the annual stomach contents, trophic level, LWR and condition factors of $M$. bleekeri from wetland ecosystems in Dekhar Haor, Bangladesh. The calculated TROPH analysis allowed us to describe M. bleekeri is an opportunistic feeder and their diet varies with size and season. The seasonal variation also influenced the LWR and Fulton's condition factor of the fish, but did not affect the relative condition factor (except in October). The calculated lowest 
and highest condition factors estimated from the study during November and August allowed us to predict $M$. bleekeri's spent and recovery stages. The data obtained from this study will be useful for the fishery biologists and resource managers to impose adequate regulations for sustainable management of this important fishery resources in Dekhar Haor and nearby inland waters of Bangladesh.

\section{ACKNOWLEDGEMENTS}

We would like to thank our laboratory and field technicians of Aquatic Resource Management lab, Sylhet Agricultural University (SAU) for their efforts and support during this study. We would also like to express our sincere thanks to the two anonymous reviewers for their valuable comments that greatly improve the earlier version of this manuscript. This study was funded by the University Grants Commission of Bangladesh (UGC) through Sylhet Agricultural University Research System (SAURES) fund grant (Grant no. SAU/director (Research)-68/17/303(8)). Thanks to UKM for supporting the publication fee through the research grant ZF-2019003.

\section{REFERENCES}

Abdel-Aziz, N.E. \& Gharib, S.M. 2007. Food and feeding habits of round (Sardinella aurita) in El-Mex Bay, Alexandria Egypt. Egyptian Journal of Aquatic Research 33: 202-221.

Alam, M.T., Hussain, M.A., Sultana, S., Hasan, M.T., Mazlan, A.G., Simon, K.D. \& Mazumder, S.K. 2018. Population growth and reproductive potential of five important fishes from the freshwater bodies of Bangladesh. Iranian Journal of Fisheries Sciences 17(4): 657-674.

Bagenal, T.B. \& Tesch, F.W. 1978. Age and growth. In Methods for Assessment of Fish Production in Fresh Waters. 3rd ed. Oxford: Blackwell Scientific Publications. pp. 101-136.

Blaber, S.J.M. 2000. Tropical Estuarine Fishes Ecology, Exploitation and Conservation. London: Wiley Blackwell Science Ltd. pp. 372-373.

Boys, C.A., Kroon, F.J., Tim, M., Glasby, M.T. \& Wilkinson, K. 2012. Improved fish and crustacean passage in tidal creeks following floodgate remediation. Journal of Applied Ecology 49: 223-233.

Chitravadivelu, K. \& Sivapalan, A. 1984. Food and feeding of Siganus lineatus from waters around Northern Srilanka. Journal of the National Science Council of Sri Lanka 12: 129-139.

Center for Natural Resource Studies. 2004. Management of aquatic ecosystems through community husbandry. Feasibility Report on MACH (Management of Aquatic Ecosystems through Community Husbandry).
Daliri, M., Paighambari, S.Y., Shabani, M.J., Pouladi, M. \& Davoodi, R. 2014. Length-weight and length-girth relationships, relative weight and relative condition factor of four commercial fish species of northern Persian Gulf. Annual Review \& Research in Biology 2(1): 15-26.

Das, S.K., De, M. \& Ghaffar, M.A. 2014. Length-weight relationship and trophic level of hard-tail scad Megalaspis cordyla. Science Asia 40(5): 317-322.

De, M., Ghaffar, M.A., Bakar, Y., Cob, Z.C. \& Das, S.K. 2016. Optimum temperature for the growth form of tiger grouper (Epinephelus fuscoguttatus +$) \times$ Giant Grouper $(E$. lanceolatus ふै) hybrid. Sains Malaysiana 45(4): 541-549.

Froese, R. 2006. Cube law, condition factor and weight-length relationships: History, meta-analysis and recommendations. Journal of Applied Ichthyology 22(4): 241-253.

Fulton, T.W. 1904. The Rate of Growth of Fishes. Annual Report Part III. Fishes Board of Scotland.

Goutham-Bharathi, M.P., Mohanraju, R., Krishnan, P., Sreeraj, C. \& Simon, K. 2013. Stomach contents of banded archerfish, Toxotes jaculatrix (Pallas 1767) (Toxotidae) from brackish waters of South Andaman, India. Asian Fisheries Science 26: 243-250.

Hoque, M.A. \& Hossain, M.A. 1992. Length-weight relationship and condition factor of the cat fish Mystus vittatus (Bloch) (Cypriniformes: Bagridae). University Journal of Zoology, Rajshahi University 10: 113-114.

Hossain, M.A. \& Afroze, S. 1991. Small fishes as a resource in rural Bangladesh. Fishbyte 9(2): 16-18.

Hossain, M.Y., Ahmed, Z.F., Leunda, P.M., Jasmine, S., Oscoz, J., Miranda, R. \& Ohtomi, J. 2006. Condition, length-weight and length-length relationships of the Asian striped catfish Mystus vittatus (Bloch, 1794) (Siluriformes: Bagridae) in the Mathabhanga River, southwestern Bangladesh. Journal of Applied Ichthyology 22(4): 304-307.

Hyslop, E.J. 1980. Stomach contents analysis-a review of methods and their application. Journal of Fish Biology 17(4): 411-429.

Joyce, W.N., Campana, S.E., Natanson, L.J., Kohler, N.E., Partt, H.L. \& Jenson, C.F. 2002. Analysis of stomach contents of porbeagle shark (Lamna nasus Bonnaterre) in the northwest Atlantic. Journal of Marine Science 59: 1263-1269.

Kumar, D.B., Singh, N.R., Bink, D. \& Devashish, K. 2014. Length - weight relationship of Labeo rohita and Labeo gonius (Hamilton-Buchanan) from Sone Beel, the biggest wetland of Assam. India Journal of Environmental Research and Development 8(3): 587.

Lagler, K.F. 1966. Freshwater Fishery Biology. 2nd ed. Dubuque, Iowa: WM.C. Brown Company. p. 421.

Layman, C.A., Winemiller, K.O., Arrington, D.A. \& Jepsen, D.B. 2005. Body size and trophic position in a diverse tropical food web. Ecology 86(9): 2530-2535.

Le Cren, E.D. 1951. The length-weight relationship and seasonal cycle in gonad weights and condition in the perch (Perca 
fluviatilis). Journal of Animal Ecology 20(2): 201-219.

Lopez-Peralta, R.H. \& Arcila, C.A.T. 2002. Diet composition of fish species from the southern continental shelf of Colombia. Naga, WorldFish Center Quarterly 25(3-4): 23-29.

Ma, Y., Olendzki, B.C., Li, W., Hafner, A.R., Chiriboga, D., Hebert, J.R., Campbell, M., Sarnie, M. \& Ockene, I.S. 2006. Seasonal variation in food intake, physical activity, and body weight in a predominantly overweight population. European Journal of Clinical Nutrition 60(4): 519-528.

Mazlum, R.E. \& Akgumus, S. 2019. Stomach content analysis and length-weight relationship of the Pontic shad Alosa immaculata Bennett, 1835 (Pisces: Clupeidae), from the eastern Black Sea coast of Turkey. Indian Journal of Fisheries 66(4): 39-45.

Mazumder, S.K., Ghaffar, M.A. \& Das, S.K. 2019. Exploring the suitable temperature and diet for growth and gastric emptying time of juvenile Malabar blood snapper (Lutjanus malabaricus Bloch \& Schneider, 1801). Thalassas: An International Journal of Marine Sciences 35(1): 29-41.

Mazumder, S.K., Das, S.K., Rahim, S.M. \& Ghaffar, M.A. 2018. Temperature and diet effect on the pepsin enzyme activities, digestive somatic index and relative gut length of Malabar blood snapper (Lutjanus malabaricus Bloch \& Schneider, 1801). Aquaculture Report 9: 1-9.

Mazumder, S.K., Das, S.K., Bakar, Y. \& Ghaffar, M.A. 2016. Effects of temperature and diet on lengthweight relationship and condition factor of the juvenile Malabar blood snapper (Lutjanus malabaricus Bloch \& Schneider, 1801). Journal of Zheijang University SCIENCE B-Biomedicine \& Biotechnology 17(8): 580-590.

Moutopoulos, D.K. \& Stergiou, K.I. 2002. Length-weight and length-length relationships of fish species from the Aegean Sea (Greece). Journal of Applied Ichthyology 18(3): 200-203.

Musa, A.S.M. \& Bhuiyan A.S. 2007. Fecundity of Mystus bleekeri (Day, 1877) from the River Padma near Rajshahi city. Turkish Journal of Fisheries and Aquatic Sciences 7: 161-162.

Onimisi, M.M. \& Ogbe, F.G. 2015. Length-weight relationships and condition factor for fish species of river Okura, Kogi state, Central Nigeria. International Journal of Scientific Research and Engineering Studies 2(7): 1-3.

Pandit, D., Kunda, M., Harun-Al-Rashid, A., Sufian, M.A. \& Mazumder, S.K. 2015. Present status of fish biodiversity in Dekhar Haor, Bangladesh: A case study. World Journal of Fish and Marine Sciences 7(4): 278-287.

Pauly, D., Froese, R., Sa-a, P., Palomares, M.L., Christensen, V. \& Rius, J. 2000. TrophLab Manual. International Center for Living Aquatic Resources (ICLARM).

Roy, P.K. \& Hossain, M.A. 2006. The fecundity and sex ratio of Mystus cavasius (Hamilton) (Cypriniformes: Bagridae). The Journal of Life and Earth Science 1(2): 65-66.

Simon, K.D. \& Mazlan, A.G. 2010. Trophic position of archerfish species (Toxotes chatareus and Toxotes jaculatrix). Journal of Applied Ichthyology 26: 84-88.
Simon, K.D., Mazlan, A.G. \& Cob, Z.C. 2013. Condition factors of two archerfish species from Johor coastal waters, Malaysia. Sains Malaysiana 42(8): 1115-1119.

Simon, K.D., Bakar, Y., Samat, A., Zaidi, C.C., Aziz, A. \& Mazlan, A.G. 2009. Population growth, trophic level, and reproductive biology of two congeneric archer fishes (Toxotes chatareus, Hamilton 1822 and Toxotes jaculatrix, Pallas 1767) inhabiting Malaysian coastal waters. Journal of Zhejiang University SCIENCE B 10: 902.

Sivakami, S. 1995. Fishery and biology of the carangid fish Megalaspis cordyla (Linnaeus) off Cochin. Journal of the Marine Biological Association of India 37(1\&2): 237-248.

Sokal, R.R. \& Rohlf, F.J. 1995. Biometry: The principles and practice of statistics in biological research. Hydro Biology 1995. New York: WH Freeman \& Company. p. 253.

Stergiou, K.I. \& Karpouzi, V.S. 2002. Feeding habits and trophic levels of Mediterranean fish. Reviews in Fish Biology and Fisheries 11(3): 217-254.

Tiwana, N.S., Jerath, N., Ladhar, S.S., Singh, R. \& Brraich, O.S. 2007. Threatened fishes in Punjab Wetland: Newsletter. Environmental Information System (ENVIS).

Wade, J.W. 1992. The relationship between temperature, food intake and growth of brown trout, Salmo trutta (L); fed. Natural and artificial pelted diet in earth pond. Journal of Aquatic Sciences 7: 59-71.

Sabuj Kanti Mazumder \& Mrityunjoy Kunda

Department of Aquatic Resource Management

Faculty of Fisheries

Sylhet Agricultural University

Sylhet 3100

Bangladesh

Sabuj Kanti Mazumder

Department of Genetics and Fish Breeding

Faculty of Fisheries

Bangabandhu Sheikh Mujibur Rahman Agricultural University Gazipur-1706

Bangladesh

Mohammed Mahbub Iqbal

Department of Fish Biology and Genetics

Faculty of Fisheries

Sylhet Agricultural University

Sylhet 3100

Bangladesh

Lipi Rani Basak

Department of Livestock

Ministry of Fisheries and Livestock

Government of the People's Republic of Bangladesh

Bangladesh 
Simon Kumar Das*

Department of Earth Sciences and Environment Faculty of Science and Technology

Universiti Kebangsaan Malaysia

43600 UKM Bangi, Selangor Darul Ehsan

Malaysia
Simon Kumar Das*

Marine Ecosystem Research Centre

Faculty of Science and Technology

Universiti Kebangsaan Malaysia

43600 UKM Bangi, Selangor Darul Ehsan

Malaysia

*Corresponding author; email: simon@ukm.edu.my

Received: 2 January 2019

Accepted: 31 August 2020 